\title{
Richard Putnam Allen: A Giant in International RLS/WED-Research
}

\author{
Jan Ulfberg ${ }^{1}$
}

(C) The Author(s), under exclusive licence to Springer Nature Singapore Pte Ltd. 2021, corrected publication 2021

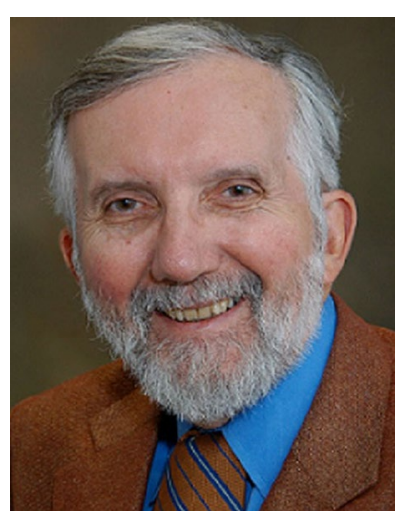

One of the most prominent sleep researchers world-wide, Richard Allen, left for the heavenly abode on December 9, 2020. Although Richard Allen was suffering of a worsening of health for past few years, he worked with a never-ending energy despite all odds.

Richard Allen was very impressive in his commitment to sleep research and particularly related to restless legs syndrome/Willis Ekbom Disease (RLS/WED). If an email was written to him, in the mailbox, there always was a response from Richard. He, perhaps possessed superhuman working capacity and seemed to work untiringly.

Richard Allen, professor in neurology, at Johns Hopkins University Hospital, Baltimore, MN, USA, contributed to, together with a large number of enthusiastic collaborators at Johns Hopkins, to create one of the most prominent and influential institution dedicated to the research on restless legs syndrome/Willis Ekbom Disease.

Efforts from Richard and his colleagues converted the opinion of the people regarding RLS. A disease entity that was earlier considered as an uninteresting ailment, nowadays is accepted as a common disease to address. He had immense empathy for patients suffering from RLS/WED and was able to understand the pain and misery they pass through.

Much of the knowledge to the world on RLS/WED was delivered to us through Richard Allens strong leadership within International RLS Study Group and his important role as a adviser to RLS Foundation in USA.

Richard Allen has published more than 350 scientific articles related to various aspects of RLS/WED. He spent decades to understand the relationship between iron and RLS/WED and it had paved way for the management of RLS using oral as well as intravenous iron. This work also benefitted the pregnant women suffering from RLS and till today is the only treatment that may be offered to them.

Richard Allen was a big friend of Sweden. He often honored the pioneering work by Prof. Karl Axel Ekbom, the neurologist who coined"restless legs" in 1945. Treatment with iron i.v. in RLS/WED, first performed by Dr Nils-Brage Nordlander, Uppsala University, in 1951, was rediscovered 40 years later by Richard Allen and his group at Johns Hopkins.

Personally, it was a pleasure to collaborate with Richard Allen in few of the projects. In addition to a few scientific papers, we wrote a book for the public,"Restless legsadvanced insights" in 2008, co-authored with the Canadian RLS/WED researcher Jacques Montplaisir.

He will be dearly missed not only by me, but also by the scientific community working to understand RLS/WED.

Publisher's Note Springer Nature remains neutral with regard to jurisdictional claims in published maps and institutional affiliations.
Jan Ulfberg

jan.ulfberg@circad.se

1 Uppsala University, Uppsala, Sweden 